\title{
Taxonomy, life cycle, distribution and dasmotrophy of Chrysochromulina: a theory accounting for scales, haptonema, muciferous bodies and toxicity
}

\author{
Kenneth W. Estep ${ }^{1}$, Ferren MacIntyre ${ }^{2}$ \\ ${ }^{1}$ Havforskningsinstituttet, Nordnesparken 2, N-5024 Bergen, Norway \\ ${ }^{2}$ A/S Pixelwerks Ltd, Postboks 1008, N-5001 Bergen, Norway
}

\begin{abstract}
This article reviews existing literature on the known Chrysochromulina species, and describes work that has been conducted on the life cycle and taxonomic affinities of these nanoplanktonic protists. In light of this information, we propose functions for the scales, muciferous bodies, and haptonema, and their relationship to toxicity, presenting a theory of auxotrophy following induced osmosis ('dasmotrophy') by cooperative assemblages of Chrysochromulina species. Dasmotrophy (from Greek $\delta \alpha \sigma \mu o \sigma$, taxation) is a form of remote parasitism. Prey organisms are compelled to return a small fraction of their contained nutrients to the environment through transient leaks in cell membranes caused by extracellular chemicals produced by Chrysochromulina. Successful dasmotrophy requires corresponding behaviour on the part of the organism, expressed as a characteristic life style and well exemplified by Chrysochromulina.
\end{abstract}

\section{INTRODUCTION}

Chrysochromulina spp. Lakey are nanoplanktonic protists, primarily marine, that exhibit a complicated life cycle and trophic mode. With rare exception, they cannot be identified to species without time-consuming electron microscope studies. In addition, they are difficult to maintain in culture and have been little studied. Interest in this genus has increased due to a bloom of C. polylepis on the Danish-Norwegian-Swedish coast causing mass mortality of fish and other animal life.

Chrysochromulina appear to be cosmopolitan in distribution, and can make up a significant percentage of the nanoplankton biomass. Chrysochromulina spp. have long been considered more enigmatic than the usual protist, and appear to be simultaneously hetero-, auto-, and osmotrophic. They are capable of ingesting bacteria, photosynthesizing, and obtaining organic carbon, the essential vitamins thiamine and cobalamin, and other nutrients from solution. In addition, they exhibit complicated behaviour and anatomy, including scales, muciferous bodies and haptonema. We here attempt to combine a number of these otherwise puzzl- ing features of Chrysochromulina into a coherent hypothesis. We stress the speculative nature of our scenario, but because many parts of it are testable, we can at least hope that rebuttal might lead to further insights.

\section{PREVIOUSLY PUBLISHED INFORMATION ON CHRYSOCHROMULINA}

Taxonomy of the genus

Chrysochromulina is a part of the Prymnesiophyceae, a group that includes the coccolithophorids. Most members of the Prymnesiophyceae are single-celled organisms, with exceptions among the coccolithophorids, Phaeocystis, which forms colonies of nonmotile cells in a gelatinous matrix (Sieburth 1979), and Corymbellus, which is basically a colonial Chrysochromulina (Green 1976).

The genus Chrysochromulina currently contains some 47 described species; 42 were listed by Estep et al. (1984), to which can be added C. pontica Rouchijanien (1966), C. orbiculata Rouchijanien (1972), C. 
brachycylindra Hällfors \& Thomsen (1985), C. inornamenta Wujek \& Gardiner (1985), and C. apheles Moestrup \& Thomasen (1986) (though it should be noted that the first 2 additions were described using light microscopy only). Of the described species, only a few are freshwater, including the type species C. parva Lakey (1939). Chrysochromulina species are distinguished by possession of 3 appendages. Two are typical $9+2$ flagella. The third appendage was originally described as a third flagellum, but is now known to be a different structure, termed the 'haptonema' (Parke et al. 1955), so named for its thread-like appearance and its ability to attach to surfaces (Figs. 1 and 2a). Unlike the flagella, the haptonema contains 6 or 7 microtubules surrounded by 3 concentric membranes (Leadbeater \& Manton 1971), and does not exhibit typical flagellar movement. Chrysochromulina is closely related to Prymnesium, a genus known for its toxicity and fish kills. Chrysochromulina is distinguished from Prymnesium on the basis of the shorter haptonema and single scale type in the latter, though there is some confusion and overlap between the genera (Green et al. 1982).

\section{Scales}

Chrysochromulina species are also distinguished by the morphology of their scale covering, a characteristic that can only be studied with the electron microscope (Figs. 1 and 2). Scales are produced in the golgi apparatus, and transported to the surface (Manton \&
Parke 1962, Leadbeater \& Manton 1969, Manton 1972). Scales on a single species may be of 1 to 4 different types, 2 types being the most common. The scales may be flat plates or shallow cones, often rimmed, and the outer layer may be differentiated into a variety of spines (Fig. 2b, c). Plate scales have a diameter that is usually about one tenth to one hundredth that of the cell, and have delicate patterns on their surfaces. There is always an 'inside' and an 'outside' to these scales, and when viewed with the electron microscope both sides of the scales can be seen, a result of the scaly covering slipping off the cell and folding during drying (Fig. 2b, c). Spines usually have a plate scale as their base, and often have 4 'struts' that hold the base of the spine (Fig. 2c). Spine scales may be longer than the body diameter, although how these are manufactured remains a mystery

Scales are composed of $65 \%$ protein and $32 \%$ carbohydrate (Allen \& Northcote 1975), and the carbohydrate appears to be cellulosic (Brown et al. 1969). The close relationship of Chrysochromulina to coccolithophorids is indicated by studies showing that the latter initially produce unmineralized plate scales similar to Chrysochromulina, on which they then deposit calcium carbonate (Leadbeater 1970, Leadbeater \& Morton 1973, Klaveness \& Paasche 1979). In fact, 'intermediate' species are known, which have lightly mineralized scales (Thomsen 1980a,b).

Although difficult to demonstrate in photographs, the scales appear to be regularly distributed over the body surface and overlapping in the manner of chain mail, as they demonstrably are in coccilithophorids (e.g. Klave-

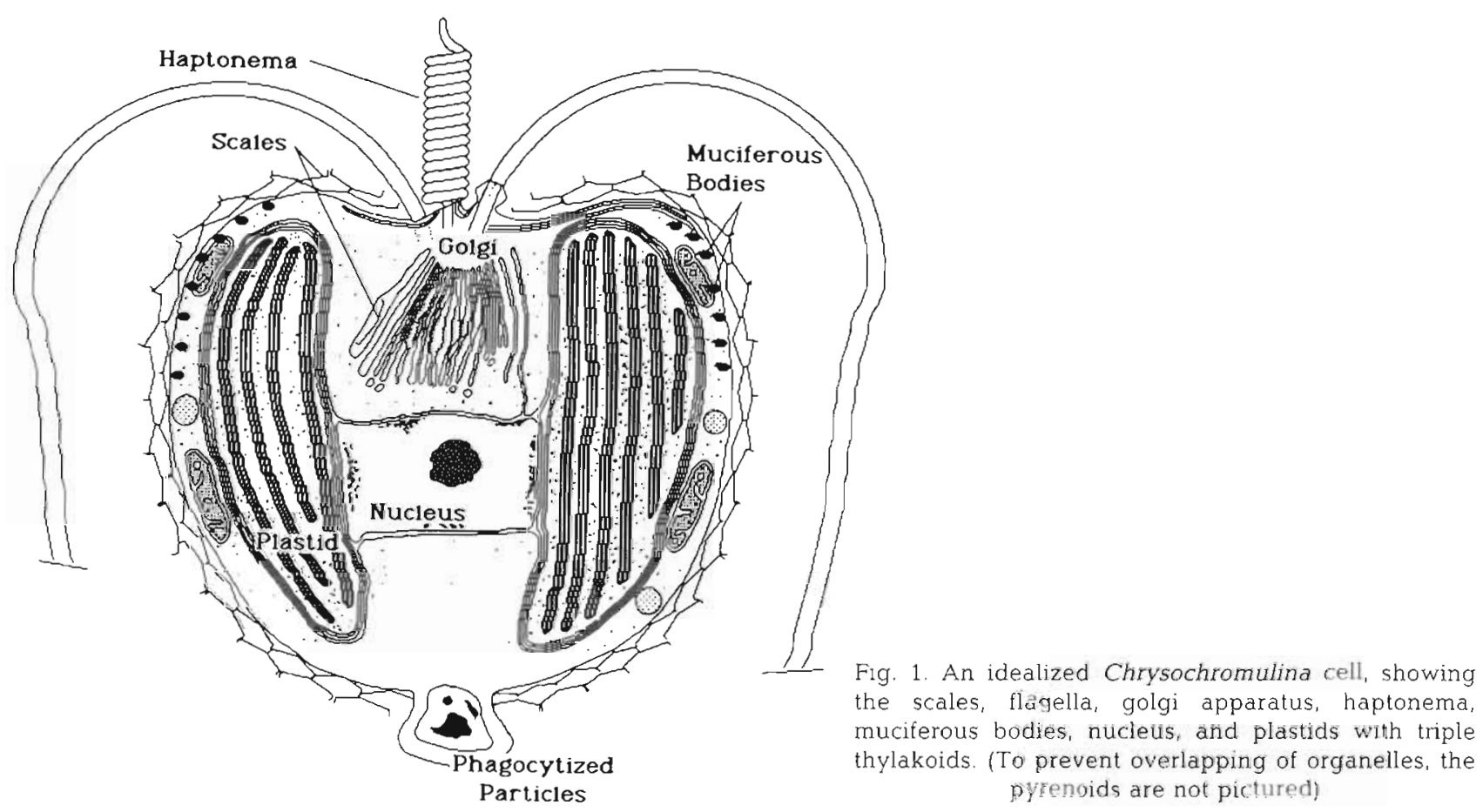



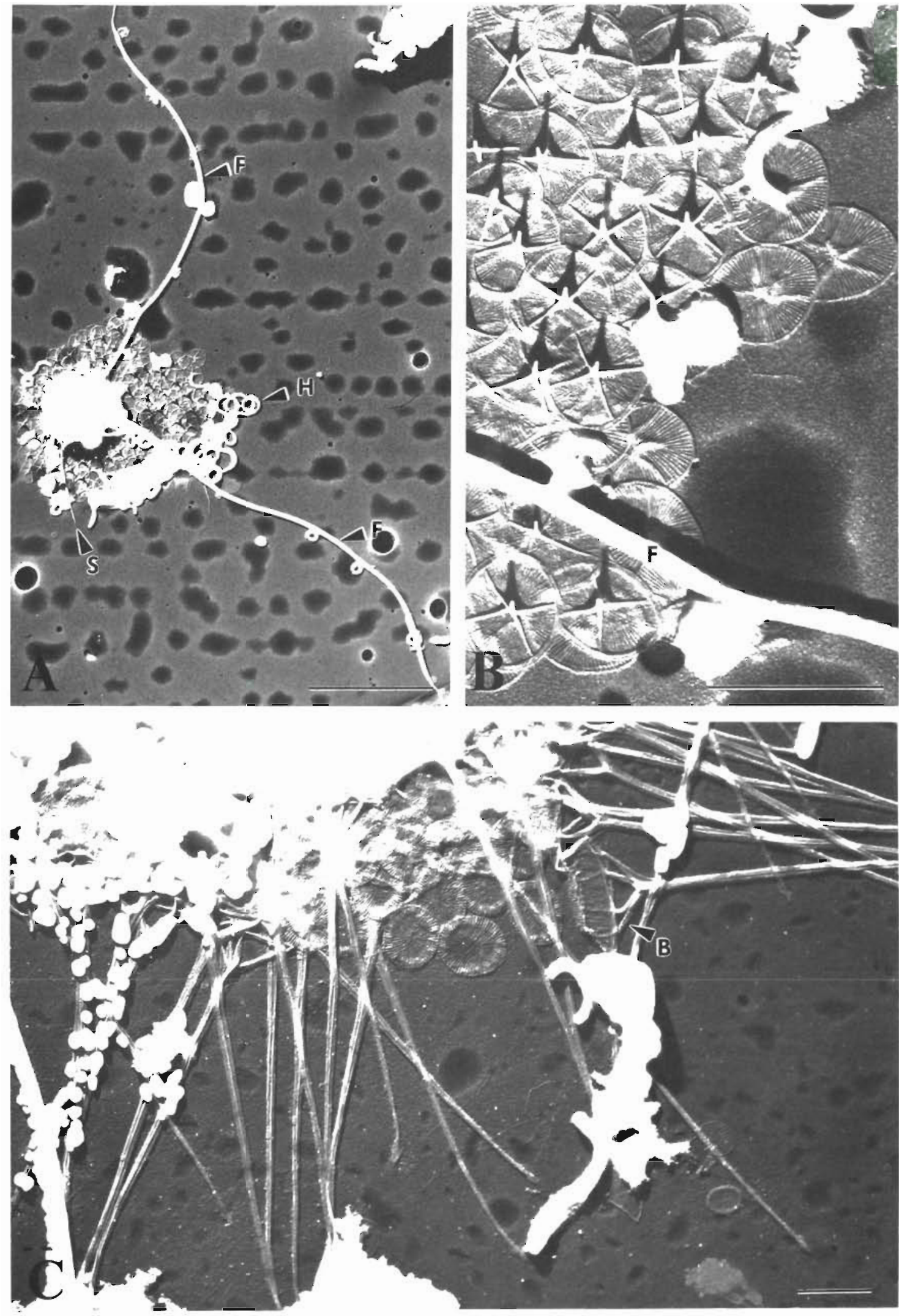

Fig. 2. Chrysochromulina species from the southern North Atlantic. (A) C elegans, whole cell showing the flagella (F), haptonema $(\mathrm{H})$, and the scale field surrounding the cell. This species has long spines (S) and one type of flat plate scale. Bar $=5 \mu \mathrm{m}$. (B) Plate scale field from $C$. elegans, both surfaces of the single type of plate scale can be seen, one with and one without a short central spine. Bar $=1 \mu \mathrm{m}$. (C) Part of the scale field from $C$. pelagica, showing both plate scales and long spine scales. The spine scales are constructed with a plate scale at their base, with an upturned rim forming a basket (B), and 4 spine struts. Bar $=1$ um 
ness \& Paasche 1979). In species with large scales, sheets of scales can detach from the body and be seen in the medium if stained with cresyl blue (Parke et al. 1958), and a regular pattern of overlapping scales can be seen in thin sections of Chrysochromulina species (Leadbeater \& Manton 1969, Manton \& Leadbeater 1974). This regularity seems to be disturbed neither by discharge of muciferous bodies nor by the ingestion of large foreign objects during phagotrophy. In at least one species, $C$. bergenensis, the scales are covered by a thin skin, which may also be temporarily opened for the purpose of phagotrophy (Manton \& Leadbeater 1974). Apparently no freeze-etched preparations have been made of Chrysochromulina, although these might go far toward resolving the problem of scale organization.

Many Chrysochromulina species are identified most easily by electron micrographs of scales, but the scales have such variable forms that there is some danger of excessive taxonomic splitting. Leadbeater (1972), for instance, remarks the relatively few cells attributable in a general way to this species included a considerable variety of minor morphological scale deviations'.

One conclusion which might be drawn from this variability is that the shape of the scales is neutral with respect to differential survival and so subject to genetic drift. This implies that the primary function of scales does not depend upon their form.

\section{Distribution}

Though Chrysochromulina is regarded as somewhat obscure (based on the paucity of publications in which it is mentioned), when specifically looked for, it often makes up a large percentage of the nanoplankton biomass in marine waters. In studies where techniques appropriate for identification of Chrysochromulina are conducted, these species have been found to make up 45 to $73.5 \%$ of the identified species, and 2.5 to $50 \%$ of the total number of nanoplankton cells (Table 1 ). Because electron-microscopic or dilution-culture techniques are needed for the recognition and identification of most Chrysochromulina species, they are usually included with the unidentified nanoplankton flagellates' Thomsen (1979), in a study of 500 electron microscope grids from Danish waters, states that

independent of season and geographical position within the area, any water sample will hold one or more species of Chrysochromulina.' Considering the fact that Chrysochromulina species have been identified in water samples from Europe (e.g. Parke et al. 1955, 1956, 1958, Manton \& Leadbeater 1974. Thomsen 1979), the Panama Canal (Wujeck 1986), South Africa (Pienaar \& Bandu 1984, Manton. \& Leadbeater 1974, Manton 1978b), Australia (Hallegraeff 1983), Arctic
Canada (Manton 1978a, Kling \& Kristiansen 1983) Alaska (Manton 1978b), the Southern North Atlantic (Estep et al. 1984), the Galapagos Islands (Manton 1983), and Japan (Throndsen 1983), we may probably extend Thomsen's statement to most samples from the world's oceans.

If Chrysochromulina are truly everywhere all the time, they are rarely present as mono-specific blooms. Chrysochromulina species are most often present in an assemblage of 4 to 25 species in the same water body, and are normally present in low cell numbers per $\mathrm{ml}$ (Table 1 ). We are aware of only a few exceptions to this general rule: the bloom of C. polylepis along the Danish-Swedish-Norwegian coast in May 1988 (Dahl et al. in press, Gjøsater \& Johannessen 1988), a fresh-water bloom of $C$. breviturrita (Wehr et al. 1985), and an under-ice bloom of C. birgeri (Hällfors \& Thomsen 1979).

\section{Life cycle}

Little work has been done on the life cycle of Chrysochromulina, due mainly to the difficulty with which it can be grown in culture. Species that have been studied exhibit a complex life cycle, with several different stages. For example, $C$. ericina reproduces asexually by fission into 2 progeny of equal or unequal size. After passing its peak in culture, it forms amoeboid cells that collect on the bottom of the culture flask. These may then form 4 walled progeny cells by successive fission. Motile cells are released from the walled cells (Parke et al. 1956). C. alifera, C. brevifilum, C. chiton, C. minor, C. kappa and C. ephippium exhibit a similar life cycle (Parke et al. 1955, 1956)

Other species show variations on this basic life cycle. Examples include Chrysochromulina pringsheimii, for which only the motile form has been seen (Parke \& Manton 1962), and C. polylepis, which may form a pseudo-filament resting stage, similar to some coccolithophorids (Manton \& Parke 1962). For the remaining Chrysochromulina species life cycle information is lacking, as most species have only been studied as preserved cells in whole-mount electron microscopy.

\section{Hyptonema and muciferous bodies}

The most distinctive characteristic of the Prymnesiophyceae is the haptonema (hence the older name for the group: Haptophyceae). The haptonema, as stated above, has 6 or 7 microtubules in a semi-circle surrounded by 3 membranes. It does not exhibit typical flagellar movement, and its usual motion is a coiling and uncoiling, though it may undergo erratic flipping or bending. Coiling is very rapid, occupying $1 / 100$ to $1 / 60$ 
Table 1 Chrysochromulina. Species as a percentage of chloroplast-containing nanoplankton species and cell numbers in various locations

\begin{tabular}{|c|c|c|c|c|c|}
\hline Location & $\begin{array}{c}\text { No. of } \\
\text { Chrysochromulina } \\
\text { species }\end{array}$ & $\begin{array}{l}\text { Chrysochromulina } \\
\text { cells } \mathrm{ml}^{-1}\end{array}$ & $\begin{array}{c}\% \text { of } \\
\text { population }\end{array}$ & $\begin{array}{l}\% \text { of } \\
\text { species }\end{array}$ & Source \\
\hline S. North Atlantic & 17 & 200 & 53.4 & 51.5 & Estep et al. (1984) \\
\hline East Australian Current & $13^{\mathrm{a}}$ & 5000 & 2.5 & $73.5^{\mathrm{b}}$ & Hallegraeff (1983) \\
\hline Bergen, Norway & 25 & ?? & $>50.0$ & 67.5 & Leadbeater (1972) \\
\hline Bay of Algiers & 18 & ?? & ?? & 45.0 & Leadbeater (1974) \\
\hline Jutland, Denmark & 19 & $? ?$ & ?? & 63.3 & Manton \& Leadbeater (1974) \\
\hline North Norway & 5 & $\leq 1000$ & 50 & 50 & Throndsen (1970) \\
\hline \multicolumn{6}{|l|}{ a Includes Phaeocystis } \\
\hline
\end{tabular}

of a second, while uncoiling takes several seconds (Leadbeater 1971). The haptonema is always coiled in death unless narcotized before killing, so the coil is the low-energy form. Though several theories for the function of the haptonema have been advanced, none have been demonstrated other than attachment to substrates. The function of the 3 enclosing membranes remains a puzzle.

When rapidly swimming, the haptonema is normally coiled. During slower swimming, it may stretch directly out in front or trail behind the cell (Parke et al. 1956, Leadbeater \& Manton 1969). The haptonema normally attaches by its distal tip, but may also attach at the middle. Several behaviour patterns have been noted after haptonemal anchoring, including rotation around the anchor in Chrysochromulina alifera (Parke et al. 1956), jumping and circling around the anchor in $C$. brevifilum (Parke et al. 1955), bending to bring the cell near the anchor in C. ephippium (Manton \& Leadbeater 1974), and drawing the cell slowly towards the anchor, after which the cell shakes itself, in C. kappa and C. minor (Parke et al. 1955).

Despite the extensive behavioural data that shows the haptonema attaching to substrates, it is often said in the literature that the purpose of the haptonema is not attachment, probably as a result of the statement in Leadbeater (1971): 'Under normal culture conditions, cells do not show much inclination towards attaching to the surface of the culture vessel or to a glass slide placed in the culture... [and therefore the haptonema] ... is not concerned with attachment'. Leadbeater also excludes 'phagotrophy, sensitivity [and] flotation' as haptonemal functions. Despite this, Leadbeater has excellent ciné photographs of the haptonema in fact attaching, and it is difficult to believe that this complicated behaviour is a matter of chance, and not its main function. We would modify his statement by appending after 'attachment' the words 'to glass surfaces'
Another feature of Chrysochromulina, though less well known than the haptonema, is the presence of muciferous bodies (Fig. 1), which appear as electrondense globules near the surface of the cell in all Chrysochromulina species that have been examined with thin-section electron microscopy (Table 2). The muciferous bodies are so named because they discharge mucus into the medium surrounding the Chrysochromulina cells. Mucus may be liberated quickly as threads or slowly as globules (Manton \& Leadbeater 1974). Threads may extend to a length of $90 \mu \mathrm{m}$ (Parke et al. 1956). Discharge of the muciferous bodies is apparently under chemosensory control. In $C$. ericina, for example, the muciferous bodies are not normally discharged, but may be discharged when 'certain other organisms have been added to the culture' (Parke et al. 1956). Parke et al. (1956) tested 9 protist species for possible phagotrophy by $C$. ericina. Six of these species were preyed upon. Three of the 4 species not consumed caused Chrysochromulina to eject muciferous threads. One of the species consumed (Chlorella sp.) also caused muciferous-body discharge, but Chrysochromulina cells disintegrated after consuming these cells. Addition of inert graphite particles (which were also consumed) did not result in muciferous-body discharge.

\section{Nutrition}

Prymnesiophyceae are basically photosynthetic organisms with large and well-developed chloroplasts, and as such might be expected to be autotrophic. Chrysochromulina species are also phagotrophic, consuming detritus, bacteria, and other protists. Phagotrophy has been observed in cultures of $C$. alifera, $C$. bergenensis, $C$. brevifilum, $C$. ephippium, $C$. ericina, C. kappa, C. polylepis and C. pringsheimii (Parke et al. $1955,1956)$. Phagotrophy on detritus in wild material 
has been observed in samples containing $C$ ephippium and C. megacylindra (Leadbeater 1972).

However, prymnesiophytes are known to require thiamine and cobalamin $\left(\mathrm{B}_{12}\right)$ for growth, and are therefore auxotrophic (Pintner \& Provasoli 1968). They are capable of osmotrophy on dissolved organic carbon at high and low light levels, but not in complete darkness (Pintner \& Provasoli 1968). In addition, unlike other marine organisms, for example Ochromonas, they cannot be maintained in a culture of sterile rice grain and sterile seawater (Estep et al. 1986, Estep unpubl.).

The bodies of some Chrysochromulina (e.g. C. epihippium and C. alifera) are saddle-shaped, which is a surface of zero curvature (i.e. its 2 principal radii of curvature have equal magnitudes but opposite sign at every point). To maintain integrity the cell membrane must have a positive surface tension, and the equilibrium low-energy configuration is consequently spherical. The unexpected high-energy shape demands an explanation which is congruent with other features of Chrysochromulina. What does Chrysochromulina gain by expending energy to maintain the saddle? We suggest that the shape is in aid of neither photosynthesis nor motility, since with only 2 chloroplasts, changes in body shape offer little improvement in light-capturing ability, and the swimming environment of objects this small is dominated by viscosity and scarcely affected by body shape. But geometrically, the saddle maximizes (subject to the constraint of a finite and constant thickness, and ignoring edge effects) the available surface area per unit volume, and we suggest that the function of the saddle is to maximize the area available for auxotrophic chemical receptors

\section{Toxicity in Prymnesiophyceae}

Prymnesiophytes are known for producing extracellular products. Phaeocystis may secrete nearly $2 / 3$ of its assimilated carbon as a polysaccharide slime. If this extraordinarily large metabolic burden is justifiable, it is apparently so because the slime is unpalatable to fish (Savage 1930), and contains bactericidal acrylic acid (Sieburth 1960, 1961), and may thus serve to protect against predation by both the large and the small.

The prymnesiophyte Prymnesium parvum produces exotoxins of unknown. structure, particularly when phosphate-starved. These toxins act by increasing the permeability of the cell membrane and disrupting the cell's osmoregulation (Shilo 1982). The toxins are proteinaceous and denature below $60^{\circ} \mathrm{C}$ (indicating that tertiary structure is important to their function), and require cofactors to function. The toxins act rapidly on higher organisms with gills (amphibian stages lacking gills are not affected; tadpoles with gills are), and are known to increase the permeability of the gill, producing symptoms of oxygen deficiency and osmoregulatory problems (Valkanov 1964).

Chrysochromulina species (including C. polylepis) have been tested for toxicity using methods described in Abbot \& Ballantine (1957). The tested species, $C$. brevifilum, $C$. chiton, $C$. ephippium, $C$. ericina, $C$. kappa, C. minor, C. polylepis, and C. pringsheimii, were all reportedly non-toxic when the supernatant medium in which Chrysochromulina had grown was added to fish. The subsequently observed toxicity of $C$. polylepis suggests that the testing was not completely reliable, and that the other species might also prove toxic under some conditions. Toxic effects have been demonstrated for Chrysochromulina against bryozoans (Jebram 1980).

Chrysochromulina's toxin behaves quite differently from the better-known toxins of dinoflagellates (Collins 1978), which are responsible for the several varieties of shellfish poisoning. Dinoflagellate toxins are for instance non-toxic to, and often accumulated by, invertebrates. Such accumulated dinoflagellate toxins are poisonous to humans (which is why their structures have been elucidated). They are also non-proteinaceous, and on all 3 counts unrelated to Chrysochromulina toxin, which are large proteins and which appear to be non-poisonous in fish, based on feeding of affected fish to mink (Aune pers. comm.).

\section{HYPOTHESIS FOR CHRYSOCHROMULINA TOXICITY AND ITS RELATIONSHIP TO BEHAVIOUR}

\section{Dasmotrophy}

Chrysochromulina needs vitamins, and perhaps other compounds, which it cannot synthesize, but normally obtains from other organisms. The general failure of attempts to grow Chrysochromulina in axenic culture is probably a result of this dependence upon the

Table 2. Species of Chrysochromulina for which muciferous bodies have been described, and their literature references

\begin{tabular}{ll}
\hline C. acantha & Leadbeater \& Manton (1971) \\
C. alifera & Parke et al. (1956) \\
C. brevifilum & Parke et al. (1955) \\
C. chiton & Parke et al. (1958) \\
C. ephippium & Manton \& Leadbeater (1974) \\
C. ericina & Parke et al. (1956). \\
& Manton \& Leedale (1961) \\
C. kappa & Parke et al. (1955) \\
C. mactra & Manton (1972) \\
C. megacyludra & Manton (1972) \\
C. polylepis & Manton \& Parke (1962)
\end{tabular}


synthetic apparatus of other organisms. We suggest that Chrysochromulina feeds in part by a novel method which might be called remote parasitism, or auxotrophy following induced osmosis, in which it obtains essential nutrients by extracting them from other organisms. The method suggested for inducing excess osmosis is by increasing the permeability of the membranes of surrounding cells, which then leak nutrients into the medium where Chrysochromulina can find them. As this appears to be a novel trophic approach, it deserves a name of its own, for which we propose 'dasmotrophy', (from $\delta \alpha \sigma \mu_{0}$, meaning tribute or tax, since it resembles nothing so much as 'You want to live in my ocean, you pay me $10 \%$ '). Dasmotrophy will be most efficient if the toxin is released only when the organism is in need of nutrients (as might happen in a bloom where there is much intraspecific competition for the nutrient), and in the presence of 'taxable' prey, as seems to be the case.

The simplest hypothesis which explains the available data is that the Chrysochromulina 'toxin' simply punches a hole in the cell membrane of other organisms. This produces the desired nutrient leakage at low concentration, and explains the observed osmoregulatory problems at high concentration and the observed indiscriminate selection of prey. The earliest self-replicating structures would seem to have required a nucleic-acid like element to specify what was being replicated, a membrane to enclose the necessary replication tools, and some way of communicating with the world outside the membrane. This last role is filled by membrane-spanning proteins, which have thus had a long time to evolve. A common molecular form which fills many useful roles (Bonner et al. 1987, Kobilka et al. 1987. Julius et al. 1988) consists of 7 or more alphahelical segments of approximately 22 residues joined by flexible links 6 to 50 residues long. The helices are lipophilic on one side and hydrophilic on the other (Lear et al. 1988) so that they assemble in the membrane to form an aqueous channel. The links, in addition to providing flexibility, also carry sites which recognize cell membrane surfaces, and opsins, neurotransmitter receptors, and pheromone receptors, also carry receptors for extracellular substances and for specific intracellular molecules (Levitzki 1988). This wide variety of functions has made such hole punches an attractive study target for synthetic chemists, and several groups have recently designed (Regan \& DeGrado 1988) or modelled (Lear et al. 1988) such molecules. Organisms use hole punches aggressively in many ways: cytotoxic T-lymphocytes kill target cells with perforin (Young et al. 1986) which, like prymnesiophyte toxins, requires $\mathrm{Ca}^{2+}$ as a cofactor (Shilo 1982), bee venom disrupts cell walls with mellitin (Tosteson 1987), and Escherichia coli uses colicins as antibiotics (Lazdunski et al. 1988). A pictorial example of a 10-helix hole punch attacking a membrane is given in Parker et al. (1989); and an intentionally lethal version of the process is described in detail in Young \& Cohn (1988)

For the same reasons that virulent pathogens tend to evolve into harmless symbionts, organisms which live by dasmotrophy should evolve methods which do not kill their prey. One might expect that the biomass of dasmotrophs would be small compared to that of their prey, and that holes would be open only a small fraction of the time (Lear et al. 1988), to ensure a certain amount of leakage without, so to speak, killing the goose that is laying the golden eggs. The most common state for Chrysochromulina is just this type of community - an assemblage of several species in the same water mass, forming a significant, but nonbloom, concentration. Chrysochromulina in this type of cooperative assemblage, protected from its own toxin by its scales, would represent a stable, taxing body. The 'toxin' of Chrysochromulina is, according to this view, not intended to be death-dealing at all, and becomes deadly only incidentally, in the rare instances when the numbers of Chrysochromulina become excessive.

Gills damaged by membrane punching will obviously show oxygenation and osmoregulatory problems. and the recovery observed when poisoned fish are moved to clean water requires only that the punches be removed by a repair system responsible for maintaining membrane integrity. Paralysis of higher organisms can arise because the electrical signal along a nerve depends upon differential sodium-potassium flows. The resting nerve cell pumps $\mathrm{Na}^{+}$out and $\mathrm{K}^{+}$in: the signal consists of opening gates which let these ions come to equilibrium. This allows the nerve to 'charge its batteries', as it were, during non-transmitting rest periods, while the actual signal itself is diffusionpowered and downhill. A single hole punched in the nerve membrane will destroy its local ability to maintain an ionic gradient, and thus its ability to transmit signals past the hole. Death by paralysis will follow quickly upon attack by a relatively small number of hole-punching molecules.

Loss of turgor is a common symptom of Chrysochromulina poisoning in organisms which rely upon hydraulic pressure to maintain body shape or function (Gjøsæter \& Johannessen 1988). Again, the lethality of this process is inadvertent: Chrysochromulina had no intention of actually killing the organisms which supply it with food. The parallel with human taxation is very direct: tax collectors thrive best when their prey is healthy and the amount they take can be sufficiently easily spared that no defense is initiated. 


\section{Growth cycle and scale shedding}

Scale shedding by fish is well known (Soutar 1967) and slow (2 scales per fish per day; Shackleton 1988). Scale shedding in Chrysochromulina is less understood, and we suggest that the repertoire of motions following haptonemal anchoring is designed to shake scales off. Scale production is energetically costly, requiring both sugar and nitrogen which might otherwise be used for maintenance and reproduction. This suggests that the scales must in some way return more value to Chrysochromulina than they cost, and that they play a vital role in the cellular economy. We suggest here 3 possible uses to which scales might be put.

During the night, Chrysochromulina makes new scales and places them on its exterior surface (Manton $\&$ Parke 1962). We suggest that the exterior surface of the scales is configured at the molecular level to trap free-floating punches, thus preventing them from reaching the cell membrane and solubilizing Chrysochromulina itself. Thus the first function of the scales might be the protective one of preventing suicide. Since the adsorptive lifetime of a scale is limited, they would have to be replaced regularly. Possibly after serving as protective organs for Chrysochromulina the scales are put to a second use. If the scales have adsorbed punches, consumption of loose scales by filter feeders might represent a very direct way of delivering high concentrations of punches to target organisms.

Chrysochromulina is well known as a fragile organism, rupturing under treatment such as gentle filtration which leaves even naked protists intact. We suggest that Chrysochromulina, requiring scales to protect itself from its own solubilizing hole-punches, has also come to depend upon scales for the third function of partial structural support, and that its own membrane is less robust than normal. This suggests trade-offs in which chemical and energetic resources normally devoted to membrane integrity are used instead to increase the membrane porosity of other organisms.

\section{The haptonema and muciferous bodies}

Of possible mechanisms for liberation of toxin into the environment, we believe that the most obvious is through the muciferous bodies. The ejection of large amounts of mucus to the environment is energetically costly. The muciferous bodies are clearly specialized ejectory organelles and the system is obviously not without some important function. Supporting the toxicrelease-function hypothesis is the chemosensory nature of muciferous body firing, possibly keyed toward species that cannot be consumed directly. We propose that organisms that cannot be consumed represent 'taxable' organisms that can be made permeable, and thus induced to leak nutrients or vitamins to the surrounding water

Haptonemal behaviour could also be important in dasmotrophy. If Chrysochromulina detects taxable organisms in its environment and releases hole-punches via the muciferous bodies, it would be an advantage to be close to the taxable source, and so to temporarily attach to these organisms. This idea is supported by the haptonemal behaviour that draws the cell near the anchor. In addition it is also supported by Leadbeater's statement that haptonema attachment is not a 'normal' behaviour for Chrysochromulina, as dasmotrophy is not practiced in the absence of taxable organisms, and there is no nutritional advantage to attaching to a glass surface.

Finally, we note the fairly non-selective predation practized by Chrysochromulina. The consumption of bacteria and protists would be of obvious value in obtaining vitamins and nutrients. If detrital feeding is not simply the result of eating anything the right size, it may be that detritus characteristically supports bacteria, or in the case of a clay particle, may have adsorbed organics of nutritional value.

In addition, and perhaps more important, the uptake of detritus might be of assistance in the dasmotrophic process. Ricketts (1972) found that the osmotrophic ability of Tetrahymena pyriformis was enhanced when cultures were presented with inorganic (and therefore non-nutritious) particles as 'prey organisms'. This response might be nothing more complex than an organism failing to find nourishment by heterotrophy and so trying an alternative approach.

\section{CONCLUSIONS AND RECOMMENDATIONS}

Our theory of dasmotrophy is incorporated in Fig. 3. In this theory, Chrysochromulina exhibits a variety of behaviour/trophic modes in different situations. When in the presence of organisms that it can prey upon, it consumes them. When in the presence of organism that cannot be consumed, but can be taxed, it ejects its muciferous bodies and induces leakage. Finally, if environmental conditions are not ideal, it forms resting stages.

If the theory of dasmotrophy is correct, it could apply to other Chrysochromulina species, as they all exhibit similar behaviour and structure. In fact this would be most reasonable, as they are normally present in assemblages of several species. Dasmotrophy and cooperative assemblages might then be construed as a form of genus-wide altruism which encourages this multispecies association, since any members of the 
Fig. 3. Chrysochromulina. Summary of the life cycle including the proposed theory of dasmotrophy. In the presence of organisms that it can prey upon, it consumes them. If in need of nutrients, or in the presence of organisms that cannot be consumed, but can be taxed, it ejects its muciferous bodies (carrying toxin), induces osmosis, and thrives on the resulting enriched medium. Finally, if environmental conditions are not ideal, it forms resting stages

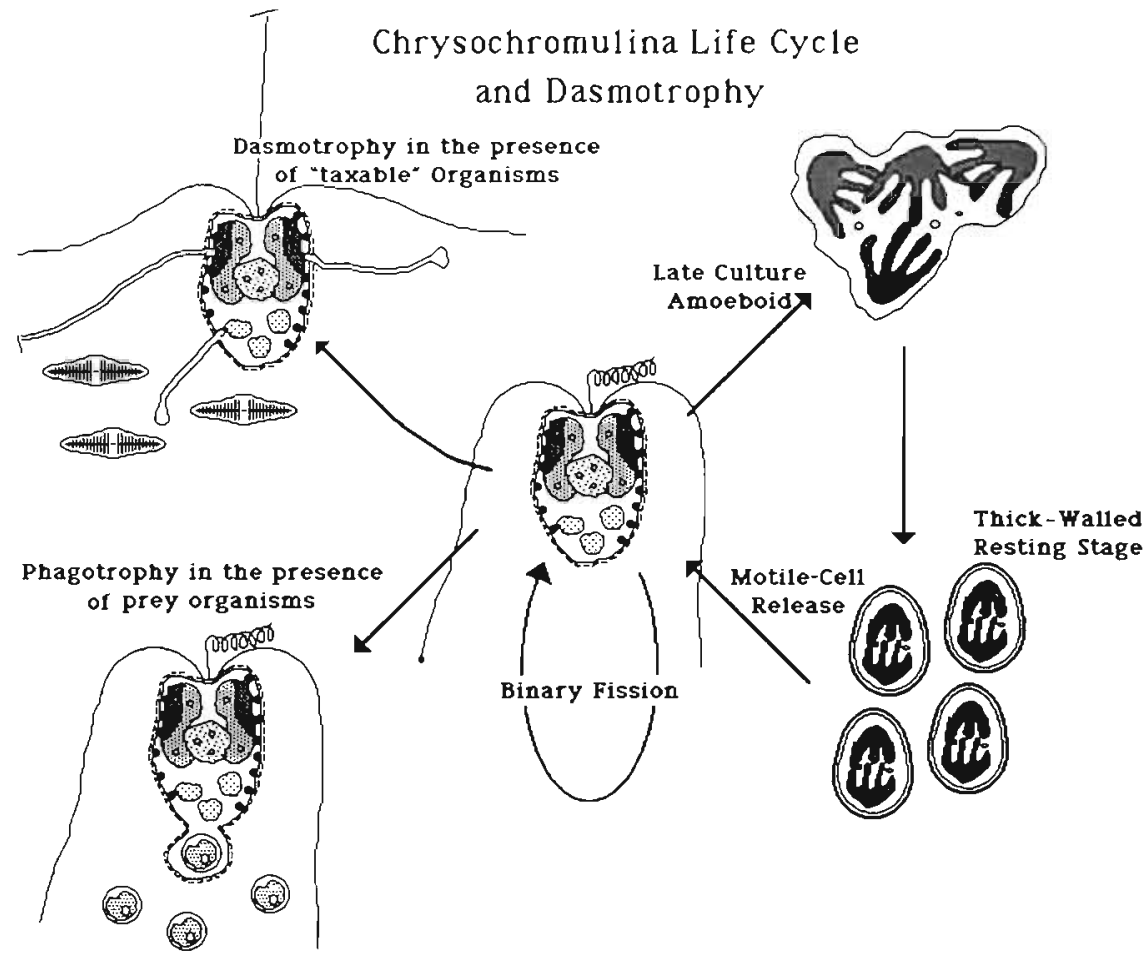

genus which happen to be present profit from the leakage induced by an individual of any species in the genus.

The estimated $\$ 5$ million economic damage produced by the May 1988 bloom of Chrysochromulina polylepis naturally leads to pressure to prevent future blooms. We emphasize that $C$. polylepis is ubiquitous in Skaggerak-Norwegian coastal waters, so that one cannot use its mere presence as an alarm indicator. In addition, its fragility and its ability to form amoeboid and resting cells makes its identification difficult: one cannot assume its absence merely because it is not found in plankton samples.

The factors which are apt to lead to noxious algal blooms have been summarized by Paerl (1988). He suggests the following preconditions:

Hydrological: A distinct water mass vertically stratified

Meteorological: Warm weather with high available light;

Chemical: Adequate nutrients including trace metals and dissolved and particulate carbon:

Topographical: Accessible sediments capable of supporting the resting stages of the bloom organism;

Ecological: An appropriate community to promote algal-bacterial synergism and minimize grazing

We note that neither water masses nor weather are under human control, and that while it is theoretically possible to increase nutrients by direct addition, it is difficult to reduce them. The life cycles and resting stages of most Chrysochromulina species are still undescribed, and the concept of a 'cooperative assemblage' (not a term used by Paerl) is so recent that one is hard put to find a description. If Pearl is right, what is usually thought of as a 'monospecific' bloom might be more completely characterized by its algal-bacterial symbionts and absence of predators.

It appears to us that it is premature to discuss the 'control' of coastal blooms, but that a case could be made for some difficult and long-term basic research. Before any question of 'management' can arise, we need the following:

(1) A larger number of clones of Chrysochromulina in culture on defined media;

(2) Further information on the behaviour and life histories of Chrysochromulina species in unialgal culture, and in the presence of other organisms;

(3) Contextual toxicity studies, leading to an understanding of toxin and muciferous-body discharge in the presence and absence of other organisms;

(4) Further information on Chrysochromulina abundance and distribution;

(5) By far the most challenging - a basic understanding of bloom communities.

We know very little about Chrysochromulina, least of all why it formed a toxic, monospecific bloom in May 1988. We do propose, however, that if our behaviourbased theory of dasmotrophy is correct, toxicity may be a fundamental aspect of most or all Chrysochromulina 
species at high concentration, which accordingly might all have the potential to form fish-killing blooms. In addition we would suggest that the 'monospecific' bloom of 1988 is not the natural state for Chrysochromulina, which heretofore has been found only in multispecies 'bloom' communities. It is hoped that the theory of dasmotrophy in this paper may provide a stimulus for further research.

Attributions and Acknowledgements. Biology by Estep, arithmetic and physical chemistry by MacIntyre, but the central concept of dasmotrophy was arrived at by both of us independently.

This work was funded in part by a grant from NTNF to Kenneth W. Estep. Thanks to Hein Rune Skjoldal and Francisco Rey for stimulating discussions about Chrysochromulina at the June 1988 Pro Mare workshop at Herdla, Norway, and to Dr John McN. Sieburth, in whose laboratory the electron microscopy was conducted. We also thank Per Flood for helpful discussions.

\section{LITERATURE CITED}

Abbot, B. C., Ballantine, D. (1957). The toxin from Gyrodinium veneficum Ballantine. J. mar. biol. Ass. U.K. 36: 169-189

Allen, D. M., Northcote, D. H. (1975). The scales of Chrysochromulina chiton. Protoplasma 83: 389-412

Bonner, T. I., Buckley, N. N., Young, A. C., Brann. M. R (1987). Identification of a family of muscarinic acetylcholine receptor genes. Science 237: 527-532

Brown, R. M., Franke, W W., Kleinig, H. Falk, H., Sitte, P. (1969). Cellulosic wall component produced by the golgi apparatus of Pleurochrysis scherffelii. Science 166 894-896

Collins, M. (1978). Algal toxins. Microb. Review. 42: 725-746

Dahl, E., Lindahl, O., Paasche, E., Throndsen, J (in press). The Chrysochromulina polylepis bloom in Scandinavian waters during spring 1988. In: Cosper, E. M., et al. (eds.) A novel phytoplankton bloom. Causes and effects of recurrent brown tides. Spring Lecture Notes on Coastal and Estuarine Studies

Estep, K. W. Davis, P. G., Hargraves, P. E., Sieburth, J. McN (1984). Chloroplast containing microflagellates in natural populations of North Atlantic nanoplankton, their identification and distribution; including a description of five new species of Chrysochromulina (Prymnesiophyceae). Protistologica 20:613-634

Estep, K. W., Davis, P. G., Keller, M., Sieburth, J. McN. (1986) How important are oceanic algal nanoflagellates in bacterivory. Limnol. Oceanogr. 31 646-650

Gjøsæter, J., Johannessen, T (1988). Algeoppblomstringen I Skagerrak mai 1988: Effekter på bunnfauna, resultater av undersokelser med dykking, strandnot og garn på sørlandskysten. Statens Biologiske Statsjon Flødevigen Rapport, p. $1-48$

Green, J. C. (1976). Corymbellus aureus gen et sp. nov., a new colonial member of the Haptophyceae. J. mar biol Ass. U.K. 56. 31-38

Green, J. C, Hibberd, D. J., Pienaar, R. N. (1982). The taxonomy of Prymnesium (Prymnesiophyceae) including a description of a new cosmopolitan species, $P$. pateliffera sp. nov, and further observations on $P$. parvum $N$ Carter Br. Phycol. J. 17: 363--382

Hallegraeff, G. M. (1983). Scale-bearing and Ioncate nano- plankton from the East Australian Current. Botanica mar 26: $493-515$

Hällfors, S., Thomsen, A. (1979). Further observations on Chrysochromulina birgeri (Prymnesiophyceae) from the Tvärminne archipelago, SW coast of Finland. Acta bot. fenn. 110: 41-46

Hällfors, S., Thomsen, A. (1985). Chrysochromulina brachycylindra sp. nov. (Prymnesiophyceae) from Finnish coastal waters. Nord. J. Bot. 5: 499-504

Jebram, D. (1980). Interrelations of nutrients, food uptake, and growth in bryozoans. Advances in Bryozoology. Academic Press, London, p. 121-140

Julius, D., McDermott, A. B., Axel, R., Jessell, T. M. (1988), Molecular characterization of a functional cDNA encoding the serotonin 1c receptor. Science 241: 558-564

Klaveness, D., Paasche, E. (1979). Physiology of coccolithophorids. In: Biochemistry and physiology of protozoa. Vol. 1. Academic Press, p. 191-213

Kling, H. J., Kristiansen, J (1983). Scale-bearing Chrysophyceae (Mallomonadacea) from central and northern Canada. Nord. J. Bot. 3: 269-290

Kobilka, B. K., Matsui, H., Kobilka, T S., Yang-Feng, T. L. Francke, U., Caron, M. G., Lefkowitz, R. J., Regan, J. W. (1987). Cloning, sequencing, and the expression of the gene coding for the human platelet $\mathrm{a}_{2}$-adrenergic receptor. Science 238: 650-656

Lazdunski. C. et al. (1988). The membrane channel-forming colicin-A-Synthesis, secretion, action and immunity. Biochem. biophys. Acta 947: 445-464

Lakey, J. B. (1939). Notes on plankton flagellates from the Scioto River. Lloydia 2: 128-143

Leadbeater, B. S. C. (1970). Preliminary observations on differences of scale morphology at various stages in the life cycle of 'Apistonema syracosphaera' sensu Von Stosch. Br. phycol J. 5: 57-69

Leadbeater, B. S. C. (1971). Observations by means of ciné photography on the behaviour of the haptonema in the plankton flagellates of the class Hyptophyceae. J. mar. biol. Ass. U.K. 51. 207-217

Leadbeater, B. S. C. (1972). Fine structural observations on six new species of Chrysochromulina (Haptophyceae) from Norway. With preliminary observations on scale production in C. microcylindra sp. nov. Sarsia 49: 107-124

Leadbeater, B. S. C. (1974). Ultrastructural observations on nanoplankton collected from the coast of Jugoslavia and the Bay of Algiers. J. mar. biol. Ass. U.K. 54: 179-196

Leadbeater, B. S. C., Manton, I. (1969). New observations on the fine structure of Chrysochromulina strobilus Parke and Manton with special reference to some unusual features of the haptonema and scales. Arch. Mikrobiol. 66: 105-120

Leadbeater, B. S. C., Manton, I. (1971). Fine structure and light microscopy of a new species of Chrysochromulina (C. acantha). Arch. Mikrobiol. 78: 58-69

Leadbeater, B. S. C., Morton, I. (1973). Ultrastructural observations on the external morphology of some members of the Haptophyceae from the coast of Jugoslavia. Nova Hedwiga 24: 207-233

Lear, J. D., Wasserman, Z. R., DeGrado, W F. (1988). Synthetic amphiphilic peptide models for protein ion channels. Science 240: 1178-1181

Levitzki, A. (1988). From epinephrine to cyclic AMP. Science 241: 800-806

Manton, I. (1972) Observations on the biology and microanatomy of Chrysochromulina megacylindra Leadbeater Br Phycol. J. 7: 235-248

Manton, I (1978a). Chrysochromulina tenuispina sp. nov. from Arctic Canada. Br. Phycol. J. 13: 227-234 
Manton, I. (1978b). Chrysochromulina hirta sp. nov, a widely distributed species with unusual spines. Br Phycol. J. 13. 3-14

Manton, I. (1983). Nanoplankton from the Galapagos Islands: Chrysochromulina discophora sp. nov. (Haptophyceae $=$ Prymnesiophyceae), another species with exceptionally large scales. Botanica mar 26: 15-22

Manton, I., Leadbeater, B. S. C. (1974). Fine-structural observations on six species of Chrysochromulina from wild Danish marine nanoplankton, including a description of $C$. campanulifera $\mathrm{sp}$. nov. and a preliminary summary of the nanoplankton as a whole. Biol. Skr 20:1-27

Manton, I., Leedale, G. F. (1961). Further observations on the fine structure of Chrysochromulina ericina Parke \& Manton. J. mar. biol. Ass. U.K. 41: 145-155

Manton, I., Parke, M. (1962). Preliminary observations on scales and their mode of origin in Chrysochromulina polylepis. J. mar. biol. Ass. U.K. 42: 565-578

Moestrup، Ø. Thomsen, H. A. (1986). Ultrastructure and reconstruction of the flagellar apparatus in C. apheles sp. nov. Can. J. Bot. 64: 593-610

Paerl, H. W. (1988). Nuisance phytoplankton blooms in coastal, estuarine, and inland waters. Limnol. Oceanogr 33: 823-847

Parke, M., Manton, I. (1962). Studies on marine flagellates. VI. Chrysochromulina pringsheimii sp. nov. J. mar biol. Ass. U.K. 42: 391-404

Parke, M., Manton, I., Clarke, B. (1955). Studies on marine flagellates. II. Three new species of Chrysochromulina. J. mar biol. Ass. U.K. 34: 579-609

Parke, M., Manton, I., Clarke, B. (1956). Studies on marine flagellates. III. Three further species of Chrysochromulina. J. mar. biol. Ass. U.K. 35: 387-414

Parke, M., Manton, I., Clarke, B. (1958). Studies on marine flagellates. IV. Morphology and microanatomy of a new species of Chrysochromulina. J. mar. biol. Ass. U.K. 37 209-228

Parker, M. W., Pattus, F., Tucker, A. V., Psernoglou, D. (1989). Structure of the membrane-pore-forming fragment of colicin A. Nature, Lond. 337: 93-96

Pienaar, R. N., Bandu, V (1984). A new species of Chrysochromulina (Prymnesiophyceae) from Natal inshore waters. Electron Microscop. Soc. S. Africa 14: 65-66

Pintner, I. J., Provasoli, L. (1968). Heterotrophy in subdued light of 3 Chrysochromulina species. Bull. Misaki mar. biol. Inst. 12: 25-31

Regan, L., DeGrado, W. F. (1988). Characterization of a helical protein designed from first principles. Science 241 976-978

Ricketts, T R. (1972). The interaction of particulate material and dissolved foodstuffs in food uptake by Tetrahymena pyriformis. Arch. Mikrobiol. 81. 344-349

Rouchijanien, M. I. (1966). Duae species novae e chrysophytis mobilibus maris nigri. Nov. Syst. Plant Non Vasc. 3: 10-15

Rouchijanien, M. I. (1972). Flagellatae marium australium nova. Nov. Syst. Plant. Non Vasc. 9: 11-17

This article was presented by Dr H. R. Skjoldal, Bergen, Norway
Savage, R. E. (1930). The influence of Phaeocystis on the migration of the herring. Fishery lnvest., Lond., Ser. II 12: 5-14

Sieburth, J. McN. (1960). Acrylic acid, an 'antibiotic' principle in Phaeocystis blooms in Antarctic waters. Science 132 $676-677$

Sieburth, J. McN (1961). Antibiotic properties of acrylic acid, a factor in the gastrointestinal antibiosis of polar marine animals. J. Bacteriol. 82: 72-79

Sieburth, J. MCN. (1979). Sea microbes. Oxford University Press, New York

Shackleton, L. Y (1988). Scale shedding: an important factor in fossil fish scale studies. J. Cons. int. Explor. Mer 44: 259-263

Shilo, M. (1982). The toxic principles of Prymnesium parvum In: Charmichael, $W$ (ed.) The water environment. Plenum Press, New York, p. 37-47

Soutar, A. (1967). The accumulation of fish debris in certain California coastal sediments. CalCOFI Rep. 11: 136-139

Thomsen, H. A. (1979). Chrysochromulina cyathophora (Prymnesiophyceae) from Danish coastal waters. Bot. Not. 132: 71-76

Thomsen, H. A. (1980a). Quaternariella obscura gen. et sp. nov. (Prymnesiophyceae) from West Greenland. Phycologia 19: $260-265$

Thomsen, H. A. (1980b). Wigwamma scenozonion sp. nov (Prymnesiophyceae) from West Greenland. Br. Phycol. J 15: $335-342$

Throndsen, J. (1970). Flagellates from Arctic waters. Nytt Mag. Bot. 17: 49-57

Throndsen, J. (1983). Ultra- and nanoplankton flagellates from coastal waters of Southern Honshu and Kyushu, Japan (including some results from the western part of the Kuroshio off Honshu\}. Working party on taxonomy in the Akashiwo Mondai Kenkyukai Fishing Ground Preservation Division, Research Department, Fisheries Agency, Japan, p. 1-62

Tosteson, M. T. (1987). Solid-phase synthesis of melittin: purification and functional characterization. Biochemistry, N.Y. 26: $6627-6631$

Valkanov, A. (1964). Untersuchungen über Prymnesium parvum Carter und seine toxische Einwirkung auf die Wasserorganismen. Kieler Meeresforsch. 20: 65-81

Wehr, J. D., Brown, L. M., O'Grady, K. (1985). Physiological ecology of the bloom-forming alga $C$. breviturrita (Prymnesiophyceae) from lakes influence by acid precipitation. Can. J. Bot. 63: 2231-2239

Wujek, D. E. (1986). Scale-bearing Chrysophyceae from the Panama Canal. Jap. J. Phycol. 34: 83-86

Wujek, D. E., Gardiner, W E. (1985). Chrysophyceae (Mallomonadaceae) from Florida. 2. New species of Paraphysomonas and the prymnesiophyte $C$. inornamenta. Fla Scient. 48: 59-63

Young, J. D. Cohn, Z. A. (1988). How killer cells kill. Scient. Am. 259: 28-34

Young, J. D.-E., Hentgartner, H., Podack, E. R., Cohn, Z. A. (1986). Isolation and characterization of a serine esterase from cytolytic T cell granules. Cell 44: 849-859

Manuscript first received: October 19, 1988

Revised version accepted: June 20,1989 